Simposium I Jaringan Perguruan Tinggi untuk Pembangunan Infrastruktur Indonesia, 2016

\title{
Studi Potensi Tampungan Air Sebagai Sumber Air Baku Kota Surabaya Umboro Lasminto
}

Jurusan Teknik Sipil FTSP ITS, Surabaya 60111, Indonesia

\begin{abstract}
Makalah ini menyajikan hasil studi tentang potensi (kuantitas) dari tampungan-tampungan air yang ada di Kota Surabaya untuk digunakan sebagai sumber air baku. Tujuan dari studi ini untuk mengidentifikasi kebutuhan air dan menghitung potensi tampungan air di wilayah Kota Surabaya. Studi ini dilakukan dengan menghitung keseimbangan air pada tampungan-tampungan tersebut. Volume tampungan, inflow dari curah hujan dan outflow berupa evaporasi dan pengambilan air digunakan untuk menghitung keseimbangan air. Hasil studi menunjukkan bahwa tampungan air berupa wakduk/boesem yaitu boesem Morokrembangan memiliki potensi untuk pemanfaatan air dengan debit sebesar $0.2 \mathrm{~m}^{3} / \mathrm{dt}$, sedangkan Boesem Kedurus memiliki potensi air sebesar $0.1 \mathrm{~m}^{3} / \mathrm{dt}$. Potensi tampungan air Kali Wonokromo (long storage) yang dapat dimanfaatkan sebagai air baku pada musim kemarau hanya $0.1 \mathrm{~m}^{3} / \mathrm{dt}$. Sedangkan tampungan air (long storage) di hulu Dam Gubeng (Kayun) di Kali Mas lebih besar dari Kali Wonokromo dan bisa mencukupi untuk pemanfaatan sebesar $0.5 \mathrm{~m}^{3} /$ detik. Tanah Tanah Bekas Kas Desa yang dimiliki Pemerintah Kota Surabaya tersebar di wilayah Kota Surabaya terutama di Surabaya bagian Barat dan bagian timur masingmasing memiliki luas area tidak terlalu besar sehingga bila digunakan sebagai tampungan maka kapasitas tampungnya kecil. Potensi air tanah tawar di Kota Surabaya sangat kecil yaitu hanya sekitar $0.03 \mathrm{~m}^{3} / \mathrm{dt}$.
\end{abstract}

Keywords: potensi; tampungan; air baku; Surabaya;

\section{Pendahuluan}

Kota Surabaya merupakan Ibu Kota Provinsi Jawa Timur yang memiliki luas wilayah $326 \mathrm{~km}^{2}$ dengan $80 \%$ dari wilayahnya merupakan dataran rendah dengan ketinggian 3-6 m. Pemenuhan kebutuhan air minum rumah tangga pada masyarakat di Kota Surabaya yang terus semakin meningkat seiring dengan pertambahan populasi penduduk. Pada Tahun 2014 Kota Surabaya memiliki jumlah penduduk sebesar 2.819.853 jiwa, dan jumlah penduduk yang harus dilayani oleh PDAM Surabaya sebesar 2.773.608 jiwa. Namun kondisi saat ini jumlah penduduk yang terlayani hanya sebesar 2.569.072 jiwa. Artinya cakupan pelayanan masih belum terpenuhi $100 \%$.

Perusahaan daerah air minum Kota Surabaya memiliki program pembangunan jaringan air minum perkotaan yang bertujuan untuk meningkatkan jaringan layanan air minum bagi masyarakat, dengan tolok ukur meningkatkan cakupan layanan dan menurunkan tingkat kehilangan air. Sehingga kegiatan pokoknya meliputi: peningkatan produksi air minum, distribusi dan penyediaan sambungan air minum, serta peningkatan kualitas pelayanan kepada pelanggan. Tujuan dari studi ini adalah mengidentifikasi potensi tampungan air di wilayah Kota Surabaya untuk sebagai masukan bagi pemerintah Kotamadya Surabaya dalam upaya mengembangkan prasarana dan sarana air minum di Kota Surabaya.

Berdasarkan program PDAM yang direncanakan, perlu dibuat skenario penanggulangan kebutuhan air jika proyek KPSSPAM Umbulan terlambat, diantaranya adalah berdasarkan proyeksi kebutuhan air (2015-2023), seluruh masyarakat Kota Surabaya dapat dilayani air minum pada tahun 2018 dan membutuhkan tambahan produksi air minum sebesar 1.500 liter/detik . Tambahan ini sebenarnya dapat dipenuhi bila suplai Air Umbulan sudah terealisasi. Namun sebelum suplai air dari Umbulan diperoleh perlu tahapan penambahan kapasitas produksi untuk Kota Surabaya dengan cara membuat tampungan air pada lahan yang berpotensi dijadikan sebagai tampungan. Adapun alternatif lahan yang berpotensi dijadikan sebagai tampungan air adalah lahan BTKD (Bekas Tanah Kas Desa) Kota Surabaya. Diperlukan pembangunan IPAM baru dengan kapasitas 500 liter/detik pada tahun 2019. Adapun alternative sumber air baku yang digunakan dan tersedia di Kota Surabaya adalah Kali Wonokromo, Kali Mas, Boezem Monokrembangan.

\section{Tinjauan Pustaka}

Kota Surabaya sebagaimana dengan kota lain di Indonesia yang secara geografis terletak di sekitar garis katulistiwa mengalami dua musim setiap tahun yaitu musim hujan dan musim kemarau. Pada saat musim hujan ketersediaan air melimpah bahkan sampai menyebabkan banjir, sedangkan dimusim kemarau hujan sangat jarang sehingga sering terjadi kekurangan air. Memanen air hujan dilakukan dengan menampung air hujan untuk dapat dipergunakan airnya di saat diperlukan. Memanen air hujan dapat dilakukan dengan cara menampung air hujan yang jatuh diatap atau menampung air yang jatuh di lahan [1]. Volume air hujan yang dapat ditampung dari atap relatif kecil sehingga penggunaan air biasanya hanya sebabtas keperluan air domestik saja. Tampungan air dilahan berupa kolam, waduk atau telaga dapat menampung volume air yang cukup besar yang dapat dimanfaatkan untuk penyediaan air domestik suatu kawasan maupun irigasi. Memanen air hujan adalah teknik sederhana dan murah untuk mendapatkan air [2]. Kapasitas tampungan, curah hujan, distribusi curah hujan dan penggunaan air sangat

* Corresponding author

E-mail address: umboro.lasminto@gmail.com 
mempengaruhi performa dari sistem memanen air hujan [3]. Berabab-abad yang lalu telah dilakukan memanen air hujan merupakan untuk mendapatkan sumber air di berbagai daerah yang sering mengalami kekurangan air [4]. Pemanfaatan air hujan yang dipanen berupa air untuk menyiram tanaman, mencuci, mandi dan jika kualitas airnya baik dapat digunakan untuk memasak [5].

Sebagai kota yang berada di tepi pantai, topografi Kota Surabaya sebagian wilayahnya relatif datar dengan ketinggian rendah terhadap permukaan laut. Air hujan yang jatuh di Kota Surabaya yang mengalir ke laut sangat dipengaruhi oleh pasang surut air laut. Pada saat hujan yang bersamaan dengan air laut pasang, aliran air hujan akan terhambat oleh pasang air laut. Oleh karena itu di Surabaya terdapat kolam tampungan air di hilir untuk menampung sebagai air sementara. Adanya tampungan air hujan dapat mengurangi genangan air yang terjadi di jalan maupun di lahan.

Bila diperhatikan dalam suatu siklus hidrologi pada suatu periode tertentu akan terlihat jumlah air yang datang (inflow) dan jumlah air yang pergi (outflow). Perhitungan inflow dan outflow ini dalam suatu periode tertentu disebut sebagai keseimbangan air (Water Balance). Dapat dimengerti bahwa jumlah air dipermukaan bumi ini (termasuk di atmosfer) tetap, hanya saja tempat dan bentuknya yang dapat berubah. Besarnya Runoff dapat dihitung sebagai :

$\Delta \mathrm{S}=\mathrm{I}-\mathrm{O}$

$\mathrm{I}=$ inflow

$\mathrm{O}=$ outflow

DS = Perubahan storage/tampungan

Secara keseluruhan keseimbangan air (water balance) seperti terlihat pada Gambar 1.

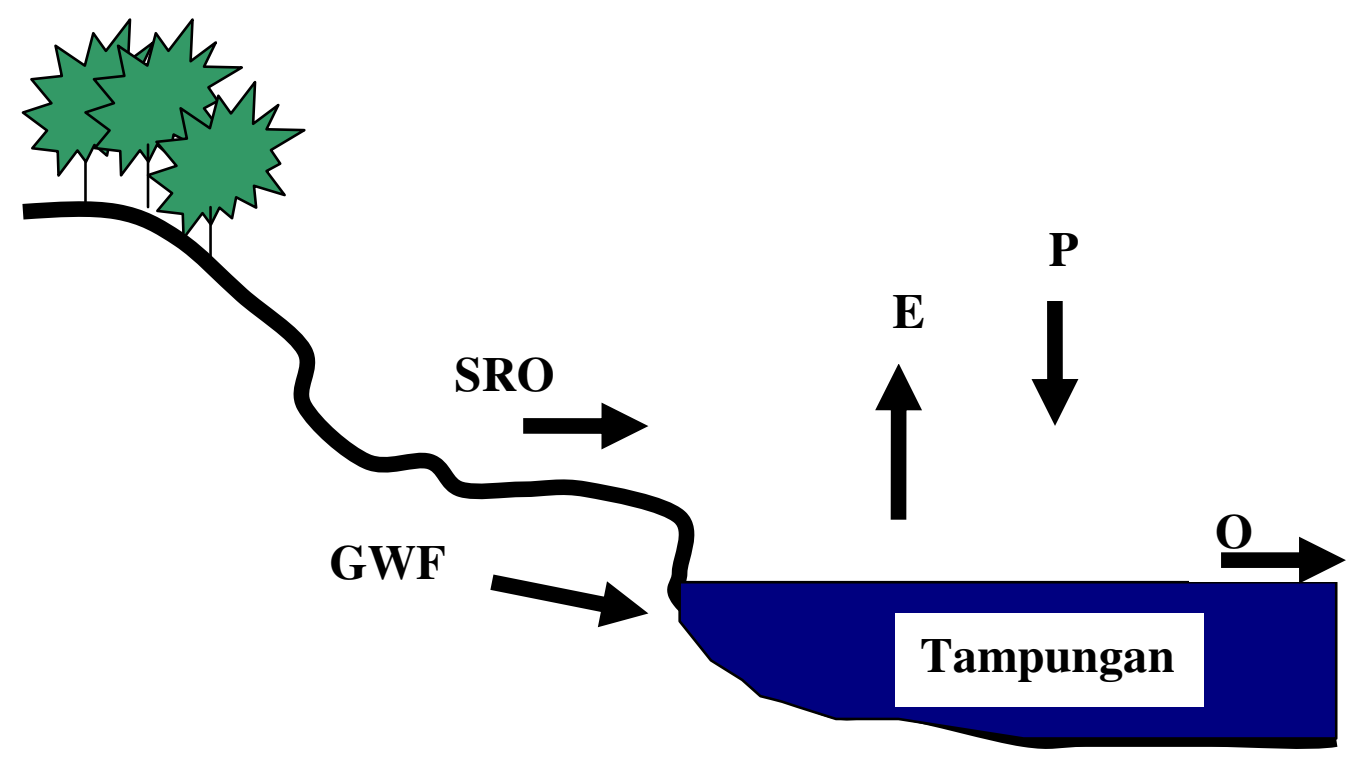

Gambar 1. Water Balance

Untuk lautan berlaku persamaan :

$\Delta \mathrm{S}=\mathrm{P}+\mathrm{SRO}+\mathrm{GWF}-\mathrm{E}-\mathrm{O}$

dimana :

$$
\begin{array}{ll}
\mathrm{P} & =\text { presipitasi (hujan) } \\
\mathrm{E}_{\mathrm{t}} & =\text { evapotranspirasi } \\
\mathrm{E} & =\text { evaporasi } \\
\mathrm{SRO} & =\text { surface runoff } \\
\mathrm{GWF} & =\text { ground water flow } \\
\Delta \mathrm{S} & =\text { perubahan storage } \\
\mathrm{O} & =\text { Pemanfaatan air }
\end{array}
$$

Untuk mengetahui besarnya debit minimum yang mengalir pada suatu sungai/Telaga/tampungan tertentu dapat diketuhi dengan menggunakan alat ukur pencatat muka air dan dengan beberapa formula maka akan diketahui hubungan antara tinggi muka air dan besarnya debit yang mengalir pada sungai tersebut, alat pencatat tersebut biasa dinamakan AWLR (Automatic Water Level Record). Akan tetapi pada beberapa sungai, seperti pada lokasi embung/telaga, tidak didapatkan alat tersebut, maka untuk mengetahui besaran debit yang mengalir maka bisa dilakukan perhitungan secara empiris. Di Indonesia metode yang 
sering dilakukan adalah metode dari DR. FJ Mock, metode NRECA dan metode Tanki (Tank model). Metode DR FJ Mock paling sering digunakan terutama di daerah dengan intensitas tinggi sampai sedang seperti daerah Sumatera, Kalimantan, Jawa dan Bali. Sedangkan metode NRECA banyak dilakukan di daerah dengan curah hujan rendah seperti di daerah nusa tenggara. Sedangkan metode Tanki jarang digunakan karena dibutuhkan data yang sangat komplek/detail terutama mengenai jenis tanah dan vegetasinya. Metode Mock adalah metode sederhana untuk memperkirakan debit dari suatu daerah aliran sungai [6]. Seperti Model Mock, model NRECA juga merupakan model sederhana yang hanya memerlukan 3 atau 4 paramater. Model ini dikembangkan oleh Norman Cran Ford [7].

\section{Hasil dan Diskusi}

Selain sungai, sistem hidrologi Kota Surabaya juga ditentukan keberadaan beberapa Waduk, Boezem dan Telaga. Ada 23 sistem hidrologi (waduk/boezem dan telaga) yang masuk dalam rekapitulasi Ruang Terbuka Hijau (RTH) publik Kota Surabaya tahun 2010. Boezem paling luas adalah Boezem Morokrembangan, dibangun pada periode kolonial Belanda dan saat ini berlangsung pekerjaan pengerukan endapan lumpur dan penggantian bangunan pembangunan oleh Proyek Sumber Air dan Pengendalian Banjir (PSAPB). Waduk/Boezem/Telaga di Surabaya banyak dimanfaatkan untuk penampungan air, irigasi, dan sebagian dimanfaatkan untuk tempat budidaya ikan. Selain Sungai dan Waduk/Boezem, sistem hidrologi yang juga berperanan adalah Telaga. Telaga-telaga ini banyak dimanfaatkan untuk drainase lingkungan sekitar. Jumlah telaga di Kota Surabaya secara keseluruhan berdasarkan data Inventarisasi Telaga oleh Badan Perencanaan dan Pembangunan Kota Surabaya adalah : Telaga Waru Gunung terbagi di tiga tempat; Telaga Lakarsantri; Telaga Sumur Welut terbagi di dua tempat; Telaga Balas Klumprik terbagi di tiga tempat; Telaga Lontar di dua tempat; Telaga Sambikerep; dan Telaga Bringin di dua tempat.

Besarnya evaporasi dapat diukur dilapangan dengan memasang alat pengukur evaporasi yaitu atmometer atau pan evaporasi. Atmometer adalah alat pengukuran evaporasi yang kecil yang biasa dipakai dalam stasiun meteorologi. Hasilnya bukan data evaluasi absolut, akan tetapi memberikan perbandingan. Perbandingan antara curah hujan dan evaporasi bulanan di Kota Surabaya disajikan pada Gambar 2. Dari gambar tersebut dapat dilihat bahwa dari bulan Januari sampai Maret dan bulan desember terjadi curah hujan bulanan yang lebih tinggi dari evaporasi sebaliknya selain bulan-bulan tersebut evaporasi bulanan lebih tinggi dari curah hujan.

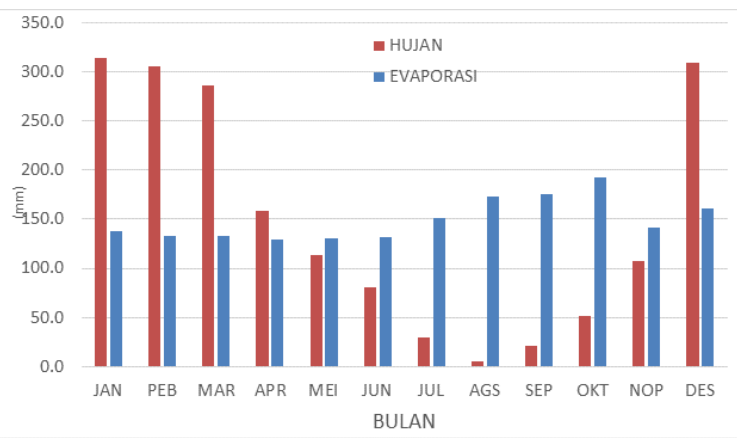

Gambar 2. Perbandingan antara tinggi hujan dan evaporasi bulanan Kota Surabaya

\subsection{Potensi air di Waduk/Boezem yang dapat dimanfaatkan sebagai Air Baku}

A. Boezem Morokrembangan

Salah satu Boezem di Kota Surabaya adalah Boezem Morokrembangan yang merupakan Boezem terluas dengan luas total \pm 78,96 ha yang terbagi menjadi dua bagian yaitu bagian selatan dengan luas $\pm 39,13$ ha dan utara $\pm 41,58$ ha. Pada tahun 2007 total luas efektif boezem hanya tinggal $\pm 46,8115$ ha. Boezem ini merupakan bagian dari sistem drainase Kota Surabaya dengan tangkapan aliran (catchment area) hampir mencapai 25\% dari luas total Kota Surabaya dengan kapasitas tampungan sebesar 1,00 hingga 1,50 juta $\mathrm{m}^{3}$. Boezem diperuntukan untuk menampung air hujan pada saat aliran puncak yang tidak dapat mengalir langsung ke laut karena kondisi pasang air laut. Sesuai dengan Perda Kota Surabaya No.2 Tahun 2004, air Boezem Morokrembangan diklasifikasikan dalam badan air kelas III, yaitu air yang peruntukannya dapat digunakan untuk pembudidayaan ikan air tawar dan air payau, peternakan, air untuk mengairi pertamanan, dan/atau peruntukan lain yang mensyaratkan mutu air yang sama dengan kegunaan tersebut. Namun, kualitas air dalam Boezem selalu melebihi standar kualitas air yang diijinkan untuk kelas III. Kondisi air di Boezem Morokrembangan pada saat ini terutama di Boezem bagian selatan sangat berbau, keruh dan berwarna kehitaman. Kondisi ini diakibatkan oleh pengendapan padatan yang berasal dari air limbah domestik yang berasal dari seluruh Catchment Area Boezem Morokrembangan. Di samping itu, aliran yang tidak terlalu lancar dari Boezem bagian selatan menuju ke bagian utara juga menambah parah kondisi Boezem selatan saat ini. Kualitas air yang jelek dari Boezem selatan berpengaruh pada kondisi air di Boezem utara. Kualitas air di Boezem utara saat ini relatif jelek, berbau dan berwarna hijau dan sebagian masih berwarna hitam ke abu-abuan.

Perhitungan keseimbangan air di Boesem Morokrembangan dilakukan dengan asumsi pengambilan air baku secara tetap sepanjang tahun. Tampungan air di dalam boesem tergantung dari tampungan awal, totak inflow dan total outflow. Hasil 
perhitungan keseimbangan air Boesem Morokrembangan disajikan pada Tabel 1.

Tabel 1. Perhitungan keseimbangan air Boesem Morokrembangan untuk pengambilan air $0.2 \mathrm{~m}^{3} / \mathrm{dt}$

\begin{tabular}{|l|r|r|r|r|r|r|r|} 
BULAN & $\begin{array}{c}\text { Tinggi } \\
\text { Hujan } \\
(\mathbf{m m})\end{array}$ & $\begin{array}{c}\text { Evaporasi } \\
\mathbf{( m m )}\end{array}$ & $\begin{array}{c}\text { Volume } \\
\text { Hujan } \mathbf{( m 3 )}\end{array}$ & $\begin{array}{c}\text { Volume } \\
\text { Evaporasi } \\
\mathbf{( m 3 )}\end{array}$ & $\begin{array}{c}\text { Air baku } \\
\mathbf{( m 3 )}\end{array}$ & $\begin{array}{c}\text { Outflow } \\
\text { Boesem } \mathbf{( m 3 )}\end{array}$ & Storage $(\mathbf{m} 3 \mathbf{)}$ \\
\hline Jan & 313 & 137 & $3,351,467$ & 91,431 & 535,680 & $1,400,000$ & $1,324,357$ \\
\hline Feb & 305 & 133 & $3,261,543$ & 88,634 & 501,120 & $2,500,000$ & $1,496,146$ \\
\hline Mar & 286 & 133 & $3,056,697$ & 88,634 & 535,680 & $2,500,000$ & $1,428,530$ \\
\hline Apr & 158 & 129 & $1,692,734$ & 85,947 & 518,400 & $1,000,000$ & $1,516,916$ \\
\hline Mei & 114 & 130 & $1,218,517$ & 86,880 & 535,680 & 600,000 & $1,512,874$ \\
\hline Juni & 80 & 132 & 859,000 & 87,590 & 518,400 & 250,000 & $1,515,883$ \\
\hline Jul & 29 & 151 & 314,867 & 100,744 & 535,680 & - & $1,194,327$ \\
\hline Aug & 6 & 173 & 59,890 & 114,885 & 535,680 & - & 603,652 \\
\hline Sep & 21 & 176 & 222,032 & 117,027 & 518,400 & - & 190,256 \\
\hline Okt & 51 & 176 & 547,074 & 117,027 & 535,680 & & 84,623 \\
\hline Nop & 108 & 193 & $1,151,185$ & 128,527 & 518,400 & 500,000 & 88,881 \\
\hline Des & 309 & 141 & $3,307,753$ & 93,917 & 535,680 & $2,600,000$ & 167,037 \\
\hline
\end{tabular}

Hasil perhitungan keseimbangan air Boesem Morokrembangan dalam tabel diatas, untuk pengambilan air baku sebesar 0.1 $\mathrm{m} 3 / \mathrm{dt}$ dan $0.2 \mathrm{~m} 3 / \mathrm{dt}$ masih dapat terpenuhi, sedangkan untuk pengambilan air sebesar $0.25 \mathrm{~m} 3 / \mathrm{dt}$ tampungan air di dalam boezem negatif artinya tidak dapat memenuhi pada bulan September, Oktober dan Nopember.

\section{A. Boezem Kedurus}

Boesem Kedurus terletak di dekat muara Kali Kedurus dengan luas 37 Ha, terbesar kedua setelah Boesem Morokrembangan. Boesem Kedurus yang hanya direncanakan untuk menampung sementara air yang datang dari hulu untuk selanjutnya dipompa menuju Kali Surabaya dihulu Dam Gunungsari, tetapi dihilir Dam Gunungsari air masuk menuju ke Kali Kedurus yang selanjutnya menuju ke Boesem sehingga seakan aliran ini hanya berputar ditempat. Kondisi ini menyebabkan operasi pompa manjadi sia sia dan akhirnya jarang dioperasikan. Dengan jarangnya pompa dioperasikan dan ditambah dengan keterbatasan anggaran maka perawatan boesem menjadi tersendat sendat dan akhirnya kondisi saat ini sudah cukup memprihatinkan. Seperti perhitungan keseimbangan air yang dilakukan pada Boesem Morokrembangan, perhitungan keseimbangan air untuk pengambilan air baku seperti disajikan pada Tabel 2.

Tabel 2. Perhitungan keseimbangan air Boesem Morokrembangan untuk pengambilan air $0.1 \mathrm{~m} 3 / \mathrm{dt}$

\begin{tabular}{|l|r|r|r|r|r|r|r|} 
BULAN & $\begin{array}{c}\text { Tinggi } \\
\text { Hujan } \\
(\mathbf{m m})\end{array}$ & $\begin{array}{c}\text { Evaporasi } \\
\mathbf{( m m )}\end{array}$ & $\begin{array}{c}\text { Volume } \\
\text { Hujan } \mathbf{( m 3 )}\end{array}$ & $\begin{array}{c}\text { Volume } \\
\text { Evaporasi } \\
\mathbf{( m 3 )}\end{array}$ & $\begin{array}{c}\text { Air baku } \\
\mathbf{( m 3 )}\end{array}$ & $\begin{array}{c}\text { Outflow } \\
\text { Boesem } \mathbf{( m 3 )}\end{array}$ & Storage (m3) \\
\hline Jan & 313 & 137 & $2,913,888$ & 50,795 & 267,840 & $2,300,000$ & 295,253 \\
\hline Feb & 305 & 133 & $2,835,705$ & 49,241 & 250,560 & $2,300,000$ & 531,157 \\
\hline Mar & 286 & 133 & $2,657,604$ & 49,241 & 267,840 & $2,400,000$ & 471,681 \\
\hline Apr & 158 & 129 & $1,471,724$ & 47,749 & 259,200 & $1,200,000$ & 436,457 \\
\hline Mei & 114 & 130 & $1,059,423$ & 48,267 & 267,840 & 700,000 & 479,773 \\
\hline Juni & 80 & 132 & 746,846 & 48,661 & 259,200 & 400,000 & 518,758 \\
\hline Jul & 29 & 151 & 273,757 & 55,969 & 267,840 & 0 & 468,706 \\
\hline Aug & 6 & 173 & 52,070 & 63,825 & 267,840 & 0 & 189,112 \\
\hline Sep & 21 & 176 & 193,043 & 65,015 & 259,200 & 0 & 57,939 \\
\hline Okt & 51 & 176 & 475,646 & 65,015 & 267,840 & & 0 \\
\hline Nop & 108 & 193 & $1,000,883$ & 71,404 & 259,200 & 800,000 & 71,009 \\
\hline Des & 309 & 141 & $2,875,881$ & 52,176 & 267,840 & $2,600,000$ & 26,874 \\
\hline
\end{tabular}

Hasil perhitungan keseimbangan air Boesem Morokrembangan dalam tabel diatas, untuk pengambilan air baku sebesar 0.05 $\mathrm{m} 3 / \mathrm{dt}$ dan $0.1 \mathrm{~m} 3 / \mathrm{dt}$ masih dapat terpenuhi, sedangkan untuk pengambilan air sebesar $0.125 \mathrm{~m} 3 / \mathrm{dt}$ tampungan air di dalam boezem negatif artinya tidak dapat memenuhi pada bulan September dan Oktober.

\subsection{Potensi Air Sungai}

Kota Surabaya merupakan bagian hilir dari sistem Sungai Brantas. Semenjak aliran Sungai Kali Brantas di alirkan ke Kali Porong, maka hanya sebagian kecil saja air Kali Brantas yang dialirkan ke Kali Surabaya. Kali Surabaya mengalirkan debit dari Kali Marmoyo dan Kali Watudakon serta limpasan air hujan di sepanjang sungai. Memasuki Kota Surabaya aliran Kali Surabaya dibagi ke Kali Wonokromo dan Kalimas. Kali Wonokromo mengalir kearah timur melewati beberapa kawasan perumahan hingga bermuara di selat Madura, sedangkan Kalimas mengalir menuju arah utara melewati beberapa kawasan perdagangan hingga bermuara di selat Madura.

\section{A. Kali Wonokromo}

Kali Wonokromo merupakan bagian dari Kali Surabaya yang direncanakan untuk mengalirkan banjir Kali Surabaya langsung ke laut tanpa melalui Kota Surabaya, dan oleh karena itu Kali Wonokromo pada awalnya disebut juga banjir kanal dimana alirannya diatur oleh Dam Jagir. Setelah di daerah Surabaya Timur berkembang dengan cepat sampai merambah daerah di sepanjang 
sungai, maka Kali Wonokromo difungsikan juga untuk menampung limpasan dari dari daerah sekitarnya melalui pompa-pompa banjir. Sampai saat ini telah ada 5 lokasi rumah pompa yang mengalirkan air dari daerah layanannya ke Kali Wonokromo, yaitu : Rumah Pompa Bratang, pompa Semolo Waru hilir yang semuanya berada di sebelah utara (di sisi kiri) Kali Wonokromo, Pompa Medokan, Rumah Pompa Kali Mir, Wonorejo I, yang berada di sebelah selatan (di sisi kanan) Kali Wonokromo.

Pada waktu musim hujan sering terjadi luapan air pada bagian tertentu. Di samping itu, aliran Kali Wonokromo dipengaruhi pasang surut air laut, dimana terjadinya air surut lebih cepat daripada terjadinya air balik pada saat air laut pasang. Oleh karena itu pada saat debit yang datang dari hulu cukup besar dan bersamaan waktunya dengan surutnya air laut, maka sering kali terjadi erosi tebing yang kemudian terjadi longsoran tanggul di beberapa tempat, hal ini menambah kemungkinan terjadinya luapan air pada saat banjir.

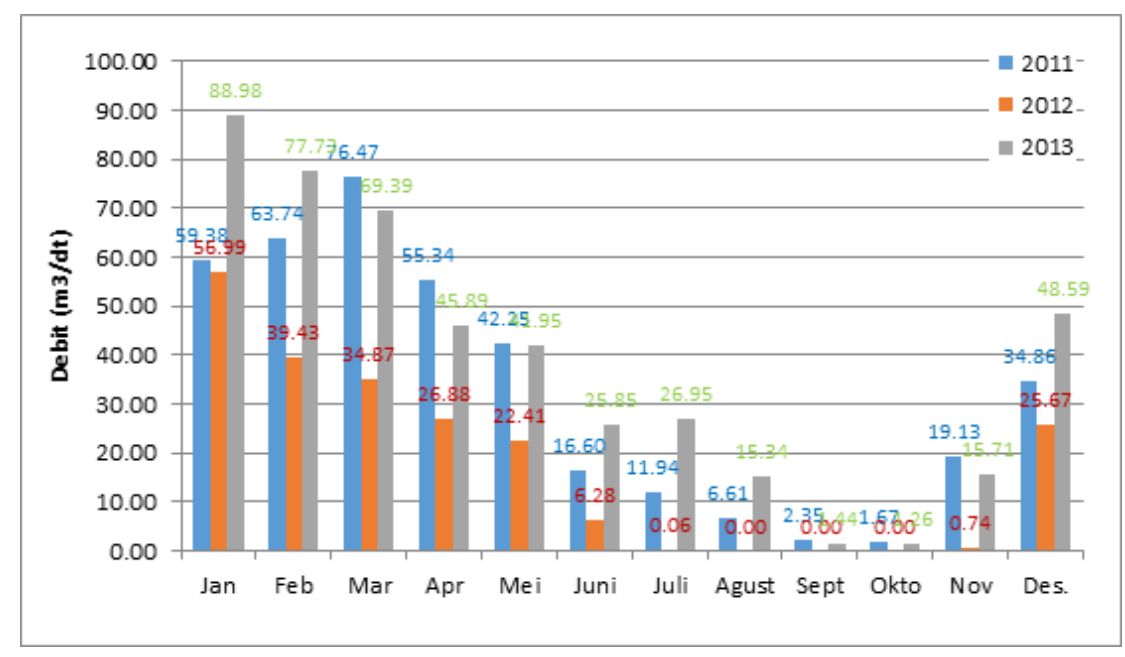

Gambar 3. Debit bulanan Kali Wonokromo dari tahun 2011-2013

Penampang Kali Wonokromo diharapkan bisa menjadi tampungan memanjang/long storage. Panjang penampang sungai yang dapat dijadikan long storage adalah 4350 meter, lebar rata-rata sungai 50 meter dan kedalaman air efektif 4 meter maka volume tampungan efektif hanya $870.000 \mathrm{~m}^{3}$. Bila direncanakan debit pengambilan air sebanyak $2 \mathrm{~m}^{3} / \mathrm{dt}$, maka volume tampungan di dalam long storage tersebut akan habis hanya selama 5 hari saja. Sedangkan bila debit pengambilan direncanakan $1.5 \mathrm{~m}^{3} / \mathrm{dt}$ maka tampungan tersebut hanya bisa memenuhi kebutuhn selama 7 hari. Bila debit pengambilan $0.5 \mathrm{~m}^{3} / \mathrm{dt}$ maka akan habis selama 20 hari. Seiring dengan berjalannya waktu di dalam penampang long storage terjadi pengendapan karena alirannya dibendung yang menyebabkan sungai menjadi semakin dangkal sehingga tampungan efektif dari long storage semakin berkurang. Dengan demikian kekurangan debit selama musim kemarau 1 s.d 5 bulan tidak dapat dipenuhi oleh tampungan dalam long storage sungai sehingga pada musim kemarau tidak ada pasokan air untuk instalasi pengelolaan air minum yang akan dibangun.

Tabel 3. Perbandingan Debit untuk pemakaian air 1, 2 dan 3 bulan selama musim kemarau

\begin{tabular}{|l|c|c|c|}
\hline Keterangan & Pemakaian 1 bulan & Pemakaian 2 bulan & Pemakaian 3 bulan \\
\hline Volume Tampungan (m3) & 870,000 & 870,000 & 870,000 \\
\hline Evaporasi (m3) & 59,377 & 115,493 & 162,255 \\
\hline Tampungan - Evaporasi & 810,623 & 754,507 & 707,745 \\
\hline Debit pengambilan (m3/dt) & 0.30 & 0.15 & 0.10 \\
\hline
\end{tabular}

Untuk pengambilan air di Kali Wonokromo perlu mempertimbangkan beberapa hal adalah sebagai berikut :

- Untuk dapat memanfaatkan air Kali Wonokromo yang telah tercampur air laut perlu dibangun bendung tetap untuk menghalangi intrusi air laut yang dapat bercampur dengan air tawar dari outflow pintu Dam Jagir. Pembangunan bendung tetap menjadi kontraproduktif dengan fungsi utama Kali Wonokromo sebagai pengalir banjir Kota Surabaya. Bila di hilir Dam Jagir dibangun bendung tetap maka aliran debit di Dam Jagir akan mengecil sehingga menyebabkan permukaan air di Kali Surabaya antara Dam Jagir dan Dam Gunungsari meningkat dan dapat meluap membanjiri lahan di kanan atau kiri sungai.

- Kali Wonokromo letaknya sudah dekat dengan laut maka kemiringan sungai sangat kecil dan perbedaan antara elevasi pasang air laut dan tebing sungai/tanggul dibeberapa penampang kecil. Keberadaan bendung tetap akan menyebabkan kenaikan muka air sungai di hulu bendung dan pada saat mengalir debit banjir air sungai dapat meluap ke jalan dan lahan permukiman di sepanjang kiri dan kanan sungai.

- Kenaikan muka air sungai juga akan berpengaruh pada aliran saluran-saluran drainase yang bermuara di Kali Wonokromo di hulu rencana bendung. Dengan muka air sungai tinggi, terjadi aliran balik pada saluran drainase yang 
akan mempengaruhi aliran air hujan di sub sistem drainase yang memiliki outlet di Kali Wonokromo, aliran air drainase menjadi hanya tergantung pada kerja pompa air.

- Bendung tetap juga akan mempercepat pendangkalan dasar sungai di hulu bendung karena sedimentasi. Akibat pendangkalan terjadi perubahan morfologi sungai dan kapasitas tampungan long storage semakin lama semakin berkurang.

- Dengan adanya bendung tetap, di musim kemarau salinitas air di hilir bendung akan meningkat karena suplay air sangat berkurang. Hal ini kemungkinan akan berdampak kepada pihak-pihak yang memanfaatkan air Kali Wonokromo.

- Kualitas air di rencana pengambilan Kali Wonokromo tentunya akan lebih rendah dari kualitas air di pengambilan hulu DAM Jagir untuk PDAM Ngagel yang disebabkan di sepanjang Kali Wonokromo terdapat beberapa outlet saluran drainase yang mengalirkan limbah kota.

- Pengambilan air dari Kali Wonokromo sulit untuk dilakukan secara gravitasi sehingga memerlukan pompa air dari sungai ke instalasi pengolah air. Operasional pompa untuk pengambilan air akan memerlukan biaya lebih mahal dibanding aliran grafitasi.

- Kali Wonokromo mengalirkan air dari outflow Dam Jagir menuju muara di Selat Madura. Dengan demikian aliran Kali Wonokromo dan muka airnya dipengaruhi oleh pasang surut air laut sehingga salinitas air sungai cukup tinggi. Untuk dapat digunakan sebagai air baku, maka salinitas air sungai perlu diturunkan dengan cara mencegah aliran balik air laut agar tidak bertemu dengan air tawar di sungai. Bangunan yang diperlukan diantara adalah bendung dengan elevasi puncak bendung lebih tinggi dari elevasi muka air pasang. Elevasi permukaan air laut pasang dari hasil pengamatan pasang surut adalah +0.88 SHVP, dengan demikian maka elevasi puncak bendung harus lebih tinggi dari elevasi muka air pasang. Kedalaman rata-rata dasar sungai adalah -5.00 SHVP sehingga tinggi bendung yang diperlukan sekitar 6 meter.

- Kali Wonokromo memiliki fungsi mengalirkan debit banjir dari Kali Surabaya dan saluran drainase Kota Surabaya ke laut. Dengan adanya bendung ini akan terjadi perubahan muka air dan dianalisa dampaknya terutama permukaan air sungai Kali Wonokromo.

Sungai Kalimas adalah salah satu hilir dari Kali Surabaya yang berfungsi sebagai sistem drainase juga berfungsi sebagai tempat wisata, penangkapan ikan, olah raga air, pelabuhan rakyat, dan penggelontor saluran pematusan. Untuk mengalirkan debit banjir, Kalimas diharapkan memberikan kontribusi untuk menyalurkan air limpasan sebesar $20 \mathrm{~m}^{3} / \mathrm{dt}$. Selain menyalurkan air dari sistem sungai Brantas, Kalimas juga menerima air limpasan hujan dari beberapa daerah pematusan yang ada di kota Surabaya sendiri sehingga total air yang dialirkan ke laut sebesar $70 \mathrm{~m}^{3} / \mathrm{dt}$.

Secara administratif, terdapat delapan Kecamatan dan 15 Kelurahan yang dilalui oleh Kali Mas. Aliran sungai ini ke arah utara Kota Surabaya dari Pintu Air Ngagel sampai kawasan Tanjung Perak memiliki bentuk sungai yang berbelok dan lurus khususnya di bagian utara. Lebar penampang permukaan sungai bervariasi antara 20- 35 meter. Bagian terlebar terdapat di Kelurahan Ngagel dengan lebar sungai sekitar 35 meter yaitu di dekat pintu air. Di daerah ini kondisi air termasuk paling bersih sehingga di sini air sungai banyak dimanfaatkan oleh warga sekitar sungai untuk mandi dan cuci. Untuk lebar sungai tersempit terdapat di Kelurahan Bongkaran yaitu dekat dengan Jalan Karet dan Jalan Coklat dengan lebar sungai sekitar 20 meter. Kedalaman Sungai Kalimas menurut data di Perum Jasa Tirta adalah antara 1-3 meter. Sedangkan kedalaman air antara 1 sampai 2 meter pada saat air laut pasang. Kedalaman sungai paling dalam berada pada kawasan Monkasel sampai kawasan Genteng. Secara relatif, ketersediaan Ruang Terbuka Hijau di sekitar Sungai Kalimas tidak luas. Lokasi yang efektif berupa Ruang Terbuka Hijau adalah di kawasan Ngagel (Taman Wisata dan sebagian Sempadan Sungai) dan di Taman Prestasi di kawasan Genteng. Fungsi utama Kalimas pada saat ini adalah sebagai tempat pembuangan air dari saluran drainase yang ada di wilayah Kota Surabaya, terutama yang berada di bagian tengah.

Aliran air di Kalimas selalu terjadi sepanjang tahun, air di Kalimas berasal dari Kali Surabaya yang lebih diprioritaskan di banding Kali Wonokromo terutama pada musim kemarau. Debit rata - rata bulanan yang mengalir di Kalimas dan tercatat di Dam Gubeng berkisar antara $2.939 \mathrm{~m}^{3} / \mathrm{dt}$ pada bulan September dan $11.763 \mathrm{~m}^{3} / \mathrm{dt}$ pada bulan Maret.

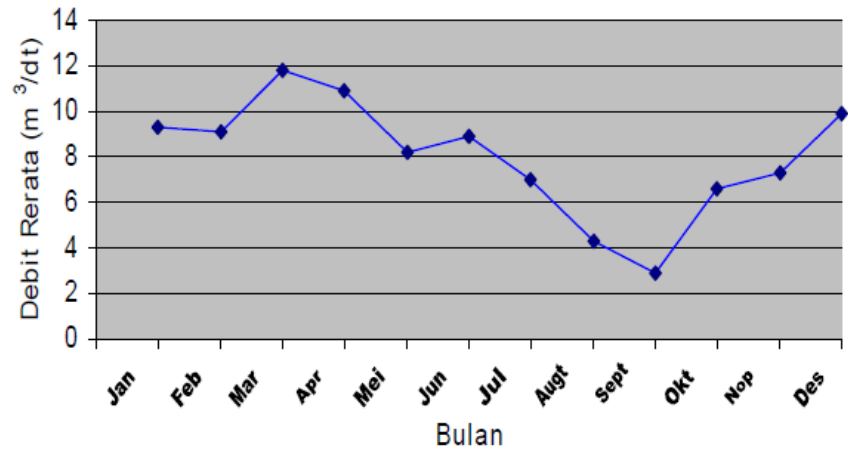

Gambar 4. Debit rata-rata bulanan Kalimas 
Pemerintah Kota Surabaya memiliki lahan-lahan bekas tanah kas desa yang tersebar di seluruh wilayah Kota Surabaya. Masing-masing lahan tidak cukup luas untuk dimanfaatkan sebagai kolam tampungan air. Luas lahan BTKD terbesar tidak mencapai $20 \mathrm{Ha}$, luas ini lebih kecil dari luas Boezem Morokrembangan maupun Boezem Kedurus. Hasil perhitungan potensi Boezem Morokrembangan dan Boezem Kedurus masing masing $0.2 \mathrm{~m} 3 / \mathrm{dt}$ dan $0.1 \mathrm{~m} 3 / \mathrm{dt}$. Dengan demikian bila lahan BTKD dimanfaatkan sebagai tampungan air maka potensi airnya akan kurang dari $0.1 \mathrm{~m} 3 / \mathrm{dt}$.

\section{Kesimpulan}

Hasil studi ini diperoleh potensi air di Kota Surabaya secara kuantitas adalah sebagai berikut :

- Dari tampungan air wakduk/boesem yaitu boesem Morokrembangan memiliki potensi untuk pemanfaatan dengan debit sebesar $0.2 \mathrm{~m}^{3} / \mathrm{dt}$, sedangkan Boesem Kedurus memiliki potensi air sebesar $0.1 \mathrm{~m}^{3} / \mathrm{dt}$. Untuk waduk/boesem/telaga yang lain dengan kapasitas tampungan lebih kecil maka potensi pemanfaatan airnya terutama dimusim kemarau juga lebih kecil dari kedua boesem tersebut.

- Potensi tampungan air Kali Wonokromo (long storage) yang dapat dimanfaatkan sebagai air baku pada musim kemarau hanya $0.1 \mathrm{~m} 3 / \mathrm{dt}$. Sedangkan tampungan air (long storage) di hulu Dam Gubeng (Kayun) di Kali Mas lebih besar dari Kali Wonokromo dan bisa mencukupi untuk pemanfaatan sebesar $0.5 \mathrm{~m}^{3} /$ detik. Kuantitas dan kontinuitas Kali Mas lebih terjamin dibandingkan Kali Wonokromo karena Perum Jasa Tirta selalu menjaga debit minimum dan maksimumnya. Kualitas air Kali Mas merupakan Sungai kelas III. Namun dalam perencanaan dibangunnya IPAM dan jaringan pipa distribusi terkendala kesulitan mendapat lahan untuk IPAM karena lokasinya yang berada di tengah kota. Bila melakukan pengambilan air untuk air baku PDAM di Kali Wonokromo (hilir Dam Jagir) perlu mempertimbangkan intrusi air laut, fungsi Kali Wonokromo sebagai pengalir banjir dan saluran-saluran drainase yang bermuara di Kali Wonokromo.

- Potensi air di Kota Surabaya untuk dimanfaatkan sebagai sumber air baku masih belum memnehui kebutuhan untuk masa datang, selain permasalahan dari segi kuantitas dan kualitas air di sungai dan boesem juga menjadi pertimbangan. Oleh sebab itu untuk memenuhi kebutuhan air dimasa yang akan datang diperlukan sumber air yang berasal dari Kota Surabaya seperti sumber mata Air Umbulan.

- Air sungai/saluran yang ada di kota Surabaya akan meningkat kualitasnya dan kemungkinan dapat digunakan sebagai air baku bilamana air limbah domestik tidak dialirkan langsung ke saluran drainase terapi secara terpisah dialiran pada instalasi pengelolaan air limbah.

- Tanah Tanah Bekas Kas Desa yang dimiliki pemkot Surabaya tersebar di wilayah Kota Surabaya terutama di Surabaya bagian Barat dan bagian timur. Luas masing-masig tanah tersebut tidak terlalu besar sehingga bila digunakan sebagai tampungan maka kapasitas tampungnya kecil.

\section{References}

[1] J. Gould and P. Nissen-Petersen, Rainwater Catchment System for domestic supply: Design, Construction and Implementation. IT Publication london.

[2] J. Worm and T. van Hattum, Rainwater Harvesting For Domestic Use., Wageningen.: Agromisa Foundation and CTA, 2006.

[3] R. M. Roebuck, C. Oltean-Dumbrava, and S. Tait, "Whole life cost performance of domestic rainwater harvesting systems in the United Kingdom," Water Environ. Journal, vol. 25, no. 3, 2010.

[4] C.-H. Liaw and Yao-Lung Tsai, “2004, Optimum Storage Volume of Rooftop Rain Water Harvesting System for Domestic Use,” J. Am. Water Resour. Assoc., vol. 40, no. 4, p. 901, 2004.

[5] W. E. Sharpe and B. Swistock, Household Water Conservation, College of Agricultural Sciences, Agricultural Research and Cooperative Extension College of Agricultural Sciences. The Pennsylvania State University., 2008.

[6] H. Mulya, J. Hadihardadja, and R. Kodoatie, "Small Islands Water Availability Analysis In Groundwater Basin (Gwb) And Non-Groundwater Basin (Non-Gwb) Using Modified Mock Calculation Method,” Int. Ref. J. Eng. Sci., vol. 2, no. 8, pp. 01-11, 2013.

[7] Z. Indra, A. B. M.I. Jasin, and J. D. Mamoto, “Analisis Debit Sungai Munte Dengan Metode Mock Dan Metode Nreca Untuk Kebutuhan Pembangkit Listrik Tenaga Air,” J. Sipil Statik, vol. 1, no. 1, pp. 34-38, 2012. 